\title{
Erratum to “ Malaria Burden in Pregnancy at Mulago National Referral Hospital in Kampala, Uganda”
}

\author{
Fatuma Namusoke, ${ }^{1}$ Niloofar Rasti, ${ }^{2}$ Fred Kironde, ${ }^{3}$ Mats Wahlgren, ${ }^{2}$ and Florence Mirembe ${ }^{1}$ \\ ${ }^{1}$ Department of Obstetrics and Gynaecology, Mulago Hospital, P.O. Box 7051, Kampala, Uganda \\ ${ }^{2}$ Department of Microbiology, Tumor and Cell Biology (MTC), Karolinska Institutet, SE-171 77 Stockholm, Sweden \\ ${ }^{3}$ Department of Biochemistry, Makerere University, P.O. Box 7072, Kampala, Uganda
}

Correspondence should be addressed to Mats Wahlgren, mats.wahlgren@ki.se

Received 7 February 2011; Accepted 27 March 2011

Copyright (c) 2011 Fatuma Namusoke et al. This is an open access article distributed under the Creative Commons Attribution License, which permits unrestricted use, distribution, and reproduction in any medium, provided the original work is properly cited.

We provide an updated Table 2.

The manuscript text has been modified as follows.

Method section 2.4, page 3, line 3, (left column): $<2500$ was changed into $\leq 2500$.

Result section 3.1, page 3, line 6-7 (right column): ... more literate $(0.001), \ldots$, used less IPT $(<0.0001)$, was changed into more literate $(0.0003), \ldots$, used less IPT (0.0002).

Discussion, page 8 , line 21 (right column): $<2500$ was changed into $\leq 2500$.

Discusson, page 9, line 22-24 (left column): Of note, significantly fewer primigravidae used IPT as compared to multigravidae (Table 2; G1 $=31.6 \%, \mathrm{G} 2-3=49.3 \%$, $\geq \mathrm{G} 4=55.7 \%$ ) was changed into Of note, significantly fewer primigravidae used IPT as compared to multigravidae (Table 2; G1 = 31.6\%, G2-3 = 49.3\%, $\geq \mathrm{G} 4=55.9 \%$ ).

Page 6, line 24, (headline of Table 5): $<2500$ was changed into $\leq 2500$.

The total number of cases in each gravidity group in Table 2 should be G1 = 196, G2-3 = 142, and $\geq \mathrm{G} 4=59$. Two cases of G3 were misclassified as G4 giving rise to reduced $\mathrm{nr}$ in the G2-3 group and increased $\mathrm{nr}$ in the G4 group. The total number of cases as depicted in the first row of the original Table 2 is still correct and should be (G1 = 196, G2-3 $=142$, and $\geq G 4=59$ ). The misclassification occurred when a reanalysis of part of Table 2 was performed and the new data was entered in the old table. The headline hence contained the correct total number of cases in each group, but the reanalysed part was based on the misclassified dataset. Since the data was entered as proportions only, the mismatch between the total number of cases in the headline and rest of the table was not detected immediately. In the corrected table, the total number in the G4 group has now decreased by 2 and in the G2-3 increased by 2. In the case of ANC-visit versus gravidity, only one case was shifted between groups as data on the second misclassified case was missing from the start. Of note, the data on placental malaria versus gravidity was not analysed on the same occasion as the other variables in the table and was thus on the correct dataset from the start. 
TABLE 1: General characteristics by gravidity.

\begin{tabular}{|c|c|c|c|c|}
\hline \multirow{2}{*}{ Characteristics } & \multirow{2}{*}{$\begin{array}{c}\text { Primigravidae (\%) } \\
\text { G1 } \\
(n=196)\end{array}$} & \multicolumn{2}{|c|}{ Multigravidae (\%) } & \multirow{2}{*}{$\begin{array}{l}P \text { value for gravidity } \\
\text { change }^{\mathrm{a}}\end{array}$} \\
\hline & & $\begin{array}{c}\mathrm{G} 2-3 \\
(n=142)\end{array}$ & $\begin{array}{c}\geq \mathrm{G} 4 \\
(n=59)\end{array}$ & \\
\hline $\begin{array}{l}\text { District of residence } \\
\text { Kampala } \\
\text { Wakiso } \\
\text { Other }\end{array}$ & $\begin{array}{c}70.2(134 / 191) \\
22.0(42 / 191) \\
7.9(15 / 191)\end{array}$ & $\begin{array}{c}67.1(94 / 140) \\
23.6(33 / 140) \\
9.3(13 / 140)\end{array}$ & $\begin{array}{c}67.2(39 / 58) \\
24.1(14 / 58) \\
8.6(5 / 58)\end{array}$ & 0.98 \\
\hline $\begin{array}{l}\text { Age (years) } \\
\quad 15-19 \\
\geq 20\end{array}$ & $\begin{array}{c}68.9(135 / 196) \\
31.1(61 / 196)\end{array}$ & \multicolumn{2}{|c|}{$85.1(171 / 201)$} & $<0.0001$ \\
\hline $\begin{array}{l}\text { Education } \\
\text { Illiterate } \\
\text { Primary } \\
\text { Higher education }\end{array}$ & $\begin{array}{c}4.4(8 / 180) \\
38.3(69 / 180) \\
57.2(103 / 180)\end{array}$ & $\begin{array}{c}7.0(9 / 129) \\
51.9(67 / 129) \\
41.1(53 / 129)\end{array}$ & $\begin{array}{c}13.0(7 / 54) \\
61.1(33 / 54) \\
25.9(14 / 54)\end{array}$ & 0.0003 \\
\hline Visit to ANC & $97.2(140 / 144)$ & $95.6(109 / 114)$ & $98.1(53 / 54)$ & 0.63 \\
\hline IPT & $31.6(62 / 196)$ & $49.3(70 / 142)$ & $55.9(33 / 59)$ & 0.0002 \\
\hline Bednet (of any kind) & $65.8(129 / 196)$ & $65.7(92 / 140)$ & $75.9(44 / 58)$ & 0.32 \\
\hline Stillbirth & $3.7(7 / 188)$ & \multicolumn{2}{|c|}{$2.0(4 / 200)$} & 0.31 \\
\hline LBW $(\leq 2500 \mathrm{~g})$ & $15.2(29 / 191)$ & \multicolumn{2}{|c|}{$9.0(18 / 200)$} & 0.06 \\
\hline Anaemia $(<11 \mathrm{~g} / \mathrm{dL})$ & $23.2(44 / 190)$ & $22.3(31 / 139)$ & $19.0(11 / 58)$ & 0.8 \\
\hline $\begin{array}{l}\text { Placental malaria } \\
\text { Active infection } \\
\text { Past infection }\end{array}$ & $\begin{array}{c}19.6(36 / 184) \\
3.8(7 / 184)\end{array}$ & $\begin{array}{c}12.5(17 / 136) \\
7.4(10 / 136)\end{array}$ & $\begin{array}{c}10.3(6 / 58) \\
0(0 / 58)\end{array}$ & 0.035 \\
\hline
\end{tabular}

ANC: antenatal clinic at least one visit during the present pregnancy.

IPT: intermittent preventive antimalaria treatment, at least one dose.

${ }^{a}$ Chi-square test used. Age, stillbirth, and LBW were analysed using multigravidae as a pooled group ( $\left.\geq \mathrm{G} 2\right)$. 


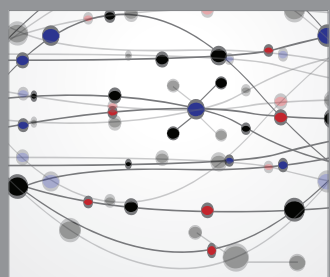

The Scientific World Journal
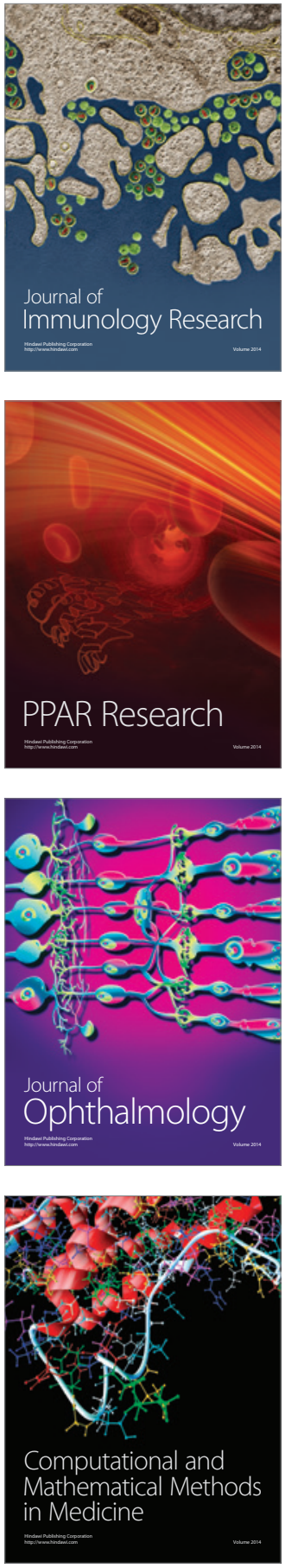

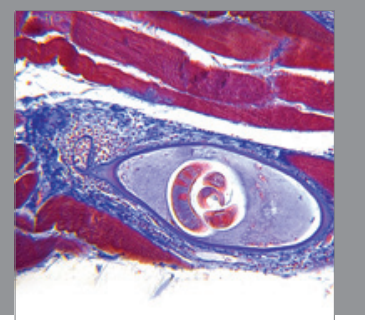

Gastroenterology

Research and Practice
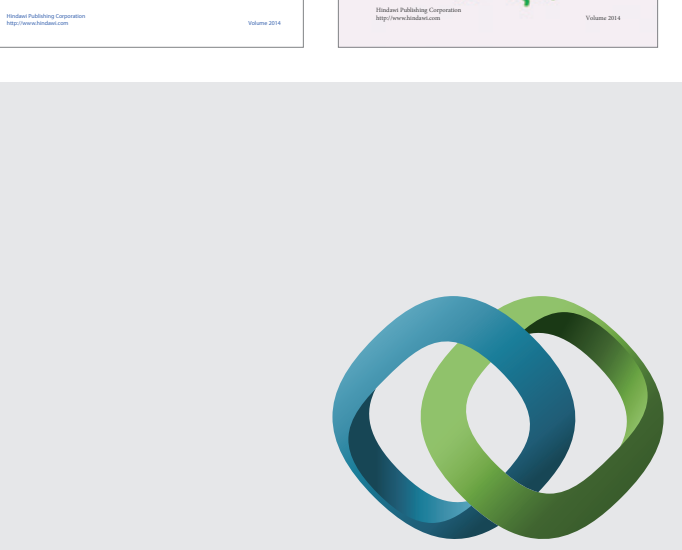

\section{Hindawi}

Submit your manuscripts at

http://www.hindawi.com
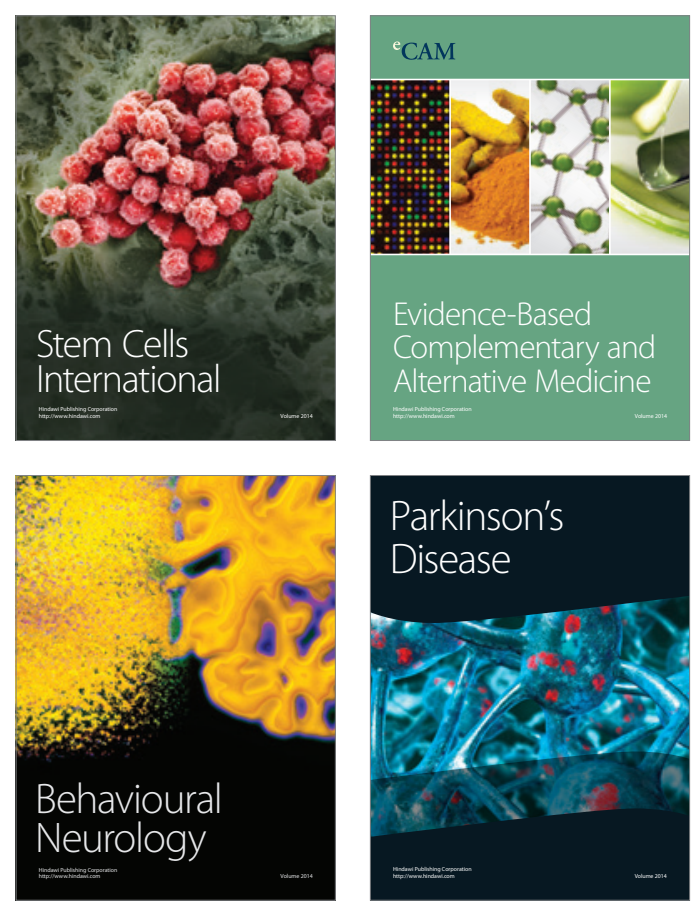

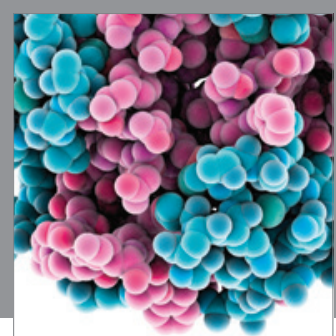

Journal of
Diabetes Research

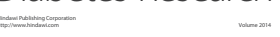

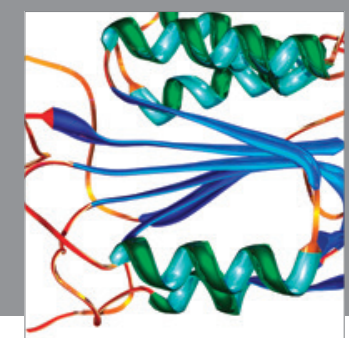

Disease Markers
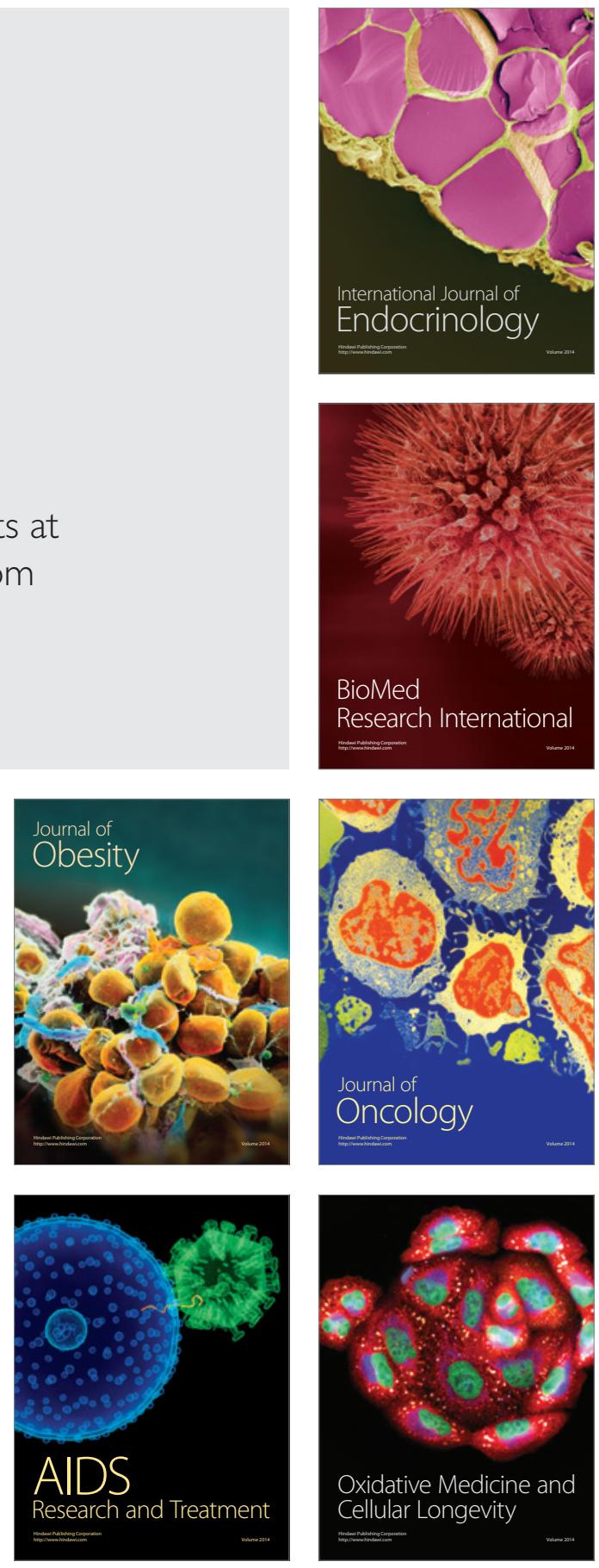